\title{
STEREOTYP MOWY UKRAIŃCA W ŚWIETLE HISTORII MÓWIONEJ (NA PODSTAWIE CHRESTOMATII HOLOSY Z PIDLASZSZIA I HOLOSY Z BERESTEJSZCZYNY HRYHORIJA ARKUSZYNA)
}

\author{
Feliks Czyżewski \\ ORCID: 0000-0003-0899-1972
}

\section{THE STEREOTYPE OF THE UKRAINIAN TONGUE IN LIGHT OF THE ORAL HISTORY BASED ON HRYHORIJ ARKUSZYN'S CHRESTOMATHY HOEOSY Z PIDLASZSZIA AND HOLOSY Z BERESTEJSZCZYNY}

\begin{abstract}
Using a sociolinguistic method, the paper discusses the linguistic awareness of the Ukrainian speaking communities of the regions of Southern Podlasie and Belorussian Polesie. The analysis of the respondents' statements found in the two volumes of Hryhorij Arkuszyn's chrestomathy identifies both the characteristic features the dialects of the two communities share and the features that are dialect-specific. As to the common characteristics present in the awareness of the local communities shaped by the respondents' historical experiences, they include references to the Second Polish Republic linked to the idea of the common state territory and the complex linguistic and confession-linked relationships ("orthodox speech"). Another common feature that transpires from the responses analyzed is a comparable communicative situation: both the local communities of the Southern Podlasie region and the region of Belorussian Polesie are bilingual and sometimes even multilingual. The paper discusses situations involving "code-switching" as seen from a sociolinguistic perspective, based, inter alia, on the criteria of the age of the respondents and their educational background.

Another important issue seen through the prism of the responses analyzed is the respondents' awareness of the dialectal links with the nation-wide tongue of the Ukrainian and Belorussian speaking communities living beyond the state borders. The analysis shows a varied linguistic awareness in this respect. Some (though not many) respondents link the language with the national awareness, others view it as an identification token of a local community. The paper discusses the respondents' statements showing the varied degrees of awareness of the Ukrainian speaking communities, depending on the respondents' age, the educational background, their mobility and their observational skills.
\end{abstract}

Key words: dialects, sociolinguistics, the Southern Podlasie region, the Belorussian Polesie region

Celem artykułu jest próba odtworzenia wiązki cech składających się na pojęcie stereotypu mowy lokalnych wspólnot ukraińskojęzycznych zamiesz- 
kujących Podlasie południowe i Polesie białoruskie. Podstawą źródłową do wydobycia elementów tworzących ów stereotyp mowy są wypowiedzi respondentów zawarte w dwutomowej chrestomatii Hryhorija Arkuszyna ${ }^{1}$ pt. Hołosy z Pidlaszszia (Teksty) ${ }^{2}$, Łuck 2007 i Holosy z Berestejszczyny (Teksty) Łuck $2012^{4}$. Dwutomowa chrestomatia prezentuje wypowiedzi ukraińskojęzycznych informatorów - przedstawicieli autochtonicznej ludności nadbużańskiej. Są to zróżnicowani wiekowo reprezentanci najstarszego pokolenia, urodzeni w latach 20.-30. ${ }^{5}$ (i nieliczni w latach 40. i 50.) XX w.

Dwutomowa chrestomatia stanowiąca dokumentację zapisów terenowych autora $^{6} \mathrm{z} 1$. dekady XXI w., opracowanych według najnowszych wymogów naukowych, jest źródłem wiedzy o kulturze i języku ludności pogranicza polsko-ukraińskiego. Publikacja ma układ dwudzielny: teksty są przywołane w zapisie fonetycznym i równolegle w zapisie literackim, zgodnie z zasadami ortografii ukraińskiej (cyrylicą); dokumentuje na ponad 1060 stronach historię mówioną Podlasia południowego i Polesia białoruskiego ${ }^{7}$. Załączone indeksy wskazują, że zagadnienia językowe stanowią wyróżniającą się część chrestomatii. Wypowiedzi respondentów obrazujące świadomość językową użytkowników gwar zostały ujęte $\mathrm{w}$ indeksie $\mathrm{w}$ formule pytania: $\mathrm{W}$ jakim języku mówicie? По якому ви говорите? ${ }^{8}$; i oznaczone w systemie numerycznym. W tomie pierwszym zastosowano układ dwóch cyfr arabskich: pierwsza

\footnotetext{
$1 \quad$ Hryhorij Arkuszyn jest profesorem Wschodnioeuropejskiego Uniwersytetu Narodowego im. Łesi Ukrainki w Łucku. Zainteresowania naukowe prof. H. Arkuszyna to głównie dialektologia i onomastyka; jest autorem wielu słowników i atlasów dokumentujących kulturę i język zachodniego Polesia. Znany jako naukowiec w środowiskach slawistycznych; stypendysta Kasy Mianowskiego w Warszawie; współautor projektu „Nekropolie pogranicza polsko-ukraińskiego". Związany z lubelskim środowiskiem naukowym; od 2001 roku jest członkiem Komisji Polsko-Ukraińskich Związków Kulturowych PAN Oddział w Lublinie.

Г. Аркушин, Голоси з Підляшия (Тексти), Луцьк 2007.

Г. Аркушин, Голоси з Берестейщини (Тексти), Луцьк 2012.

4 Hryhoryj Arkuszyn jest autorem trzech tomów tekstów gwarowych, oprócz dwu wymienionych, także: Голоси з Волинського Полісся (Тексти), Луцьк 2010. W artykule, ze względu na podjętą tematykę świadomości autochtonicznych wspólnot ukraińskojęzycznych pozostających poza granicami państwowymi Ukrainy, nie przywołuje się wymienionej publikacji, ponieważ dotyczy ona Ukraińców zamieszkałych na terytorium swojego państwa.

$5 \quad$ Pojedyncze osoby, od których pochodzą zapisy, urodziły się przed rokiem 1920.

6 Hryhorij Arkuszyn przeprowadzał wywiady terenowe na Podlasiu i Polesiu osobiście, niekiedy $\mathrm{w}$ obecności doktorantów. Część zapisów zawartych w tomie Голоси з Берестейщини pochodzi z nagrań terenowych dokonanych w latach 1982-2005 (Idem, Голоси з Берестейщини..., оp. cit, s. 6), część z lat 2010-2011 (ibidem). Te ostatnie zostały przeprowadzone $\mathrm{w}$ formie wideozapisów przy pomocy członków ukraińskiego towarzystwa „Berehynia” w Brześciu, z udziałem W. Misijuka, wiceprzewodniczącego tegoż towarzystwa.

7 Г. Аркушин, Голоси з Підляшщя..., op. cit.; idem, Голоси з Берестейщини..., op. cit.

8 Idem, Голоси з Підляшия..., op. cit. s. 532; Голоси з Берестейщини..., op. cit., s. 17.
} 
określa numer miejscowości, druga zaś numer tekstu - z danej miejscowości ${ }^{9}$; w tomie drugim zastosowano zaś połączenie cyfry rzymskiej, oznaczającej miejscowość, i cyfry arabskiej - numer tekstu z danej wsi, np. II. $3^{10}$. Wymieniony sposób identyfikacji tekstów będzie stosowany w artykule.

Materiał źródłowy poświęcony zagadnieniom świadomości językowej rdzennej ludności ukraińskojęzycznej jest bogaty. Z obszaru wschodniej Polski, tj. z województw lubelskiego i podlaskiego (od rzeki Włodawki na południu po rzekę Narew na północy) - wskazanym zagadnieniom poświęcone są następujące fragmenty chrestomatii, oznaczone numerycznie: $1.6 ; 2.1 ; 3.4$; $3.8 ; 3.9 ; 5.6 ; 7.11 ; 8.3 ; 8.9 ; 9.9 ; 10.2 ; 12.1 ; 13.2 ; 14.7 ; 15.1 ; 15.2 ; 15.6 ; 16.1$; $17.4 ; 18.2 ; 19.5 ; 20.7 ; 21.1,22.3 ; 23.7 ; 25.4 ; 25,7 ; 26.6 ; 27.9 ; 28.1 ; 28.3$; $29.5 ; 31.4 ; 32.5 ; 33.7 ; 34.4 ; 36.1 ; 37.3 ; 38.1 ; 40.2 ; 41.4^{11}$. Również teksty zawarte $\mathrm{w}$ drugim tomie, tj. $\mathrm{z}$ obszaru Białorusi, ze wszystkich rejonów obwodu brzeskiego, poświęcone kwestii świadomości językowej wspólnot ukraińskojęzycznych, zajmują - obok reprezentujących inne grupy tematyczne, znaczące miejsce w chrestomatii. Są to: I, 2; II, 3; III, 2; IV, 3; VII, 3; VIII, 4; IX, 5; XI, 3; XII, 13; XVI, 4; XVIII, 6; XIX, 4; XIX, 11; XX, 2; XXII, 3; XXVII, 3; XXVIII, 2; XXXVIII, 3; XXIX, 2; XXXVI, 6; XXXVIII, 3; XL, $3 ; \mathrm{XL}, 5 ; \mathrm{LXI}, 6^{12}$.

Omawiane dwa tomy chrestomatii łączy to, że prezentują status świadomości ${ }^{13}$ wspólnot ukraińskojęzycznych, pozostających poza granicami państwowymi Ukrainy. Spajającym elementem ich historii mówionej, szczególnie losów najstarszych przedstawicieli, urodzonych w latach 20. i 30. minionego stulecia, jest to, że miejsca ich zamieszkania znajdowały się przed rokiem 1939 w obrębie jednego państwa - II Rzeczypospolitej.

Innym elementem łączącym ludność Podlasia i Polesia są wspólne doświadczenia historii II wojny światowej. Na potrzeby lokalnych wspólnot ukraińskojęzycznych tych obszarów okupant niemiecki stworzył określone warunki administracyjne, umożliwiające dostęp do edukacji i oświaty (szerzej na ten temat w dalszej części tekstu).

\footnotetext{
9 Idem, Голоси з Підляшия..., ор. cit. s. 532.

10 Idem, Голоси з Берестейщини..., op. cit. s. 17.

11 Idem, Голоси з Підляшия..., ор. cit. s. 532.

12 Idem, Голоси з Берестейщини..., op. cit. s. 17.

13 Zagadnienie świadomości językowej użytkowników gwar jest przedmiotem wielu publikacji Haliny Pelcowej (por. m.in. H. Pelcowa, Gwara jako nośnik lokalnego i regionalnego dziedzictwa kulturowego, [w:] Niematerialne dziedzictwo kulturowe: źródto-wartości-ochrona, red. J. Adamowski, K. Smyk, Lublin - Warszawa 2019; eadem, Gwara-dziedzictwo ciagle żywe czy już zapomniane?, „Język Polski” 2016, r. 96. Szerzej na ten temat m.in. w artykule: eadem, Dialektologia jako nauka i przedmiot dydaktyki, [w:] Język i kultura pogranicza, red. A. Dudek-Szumigaj, Warszawa 2019.
} 


\section{ELEMENTY WSPÓLNE I RÓŻNE W ZAKRESIE ŚWIADOMOŚCI JĘZYKOWEJ LOKALNYCH WSPÓLNOT UKRAIŃSKOJĘZYCZNYCH}

A. Cechy łączące lokalne wspólnoty ukraińskojęzyczne na Podlasiu południowym (w granicach Polski) i Polesiu zachodnim (w granicach Białorusi).

1 Mowa $^{14}$ postrzegana przez wspólnotę ukraińskojęzyczną jako twór o określonej strukturze.

W świadomości respondentów - jak pokazują teksty chrestomatii - struktura języka lokalnej wspólnoty nadbużańskiej jest elementem identyfikującym a zarazem wyróżniającym spośród otaczających ją wspólnot. W świadomości użytkowników gwary to struktura gramatyczna i fonetyczna oraz zasób leksykalny tworzą mowę wspólnoty, która tę wspólnotę identyfikuje a zarazem wyróżnia na tle innych grup.

Odpowiedzi informatorów na pytania o wyróżniki formalne ich gwary, stawiane im przez eksploratora, świadczą o tym, że w ich świadomości są to cechy stałe mikrowspólnoty językowej. Konstrukcja tej części pracy opiera się na dialogu między eksploratorem a przedstawicielem określonej wspólnoty nadbużańskiej, podczas którego stawiane są pytania o potwierdzenie/ zaprzeczenie obecności określonych cech językowych w gwarze ich użytkowników. Materiał tekstowy ilustrujący wskazane zagadnienie jest bogaty, zarówno z południowego Podlasia, jak i z Polesia białoruskiego. Por. materiał egzemplifikacyjny dotyczący pytań i odpowiedzi:

a) Dialog eksploratora $\mathrm{z}$ informatorami dotyczący struktury fonetycznej gwary: $\mathrm{E}^{15}$.: Jak u was mówią starsi: stił czy stył?; odpowiedź informatora ze wsi Welamowycze w rejonie brzeskim brzmi: stył mówili; kus'ok stol'a. E.: A na konia jak? e, kyń, ne kuń ${ }^{16}$. Podobnie w rozmowie przeprowadzonej we wsi We-

\footnotetext{
14 Terminy mowa i język są traktowane w niniejszym artykule synonimicznie i pozostają tutaj poza ujęciem F. de Saussure'a (F. de Saussure, Kurs językoznawstwa ogólnego, Warszawa 1991). Termin mowa, używany w chrestomatii przez Hryhorija Arkuszyna, może oznaczać zarówno langue, jak i parole. Ukraiński termin mowa w opracowaniach językoznawczych występuje w znaczeniu język 'la langue'.

15 Zapisy pytań i odpowiedzi zawarte w chrestomatiach są podane cyrylicą w języku ukraińskim. Zapisy zaś $\mathrm{w}$ tekście artykułu są podawane łacinką i w tłumaczeniu autora artykułu. W uzasadnionych merytorycznie przypadkach podaje się wersję oryginalną zapisu i paralelnie - thumaczenie. Materiał egzemplifikacyjny z chrestomatii Arkuszyna zawiera pytanie stawiane przez eksploratora, w tekście artykułu oznaczane symbolem E, oraz odpowiedź informatora/ respondenta, którą podaje się kursywą. Przywołane zasady stosowania zapisu materiału źródłowego traktuje się konsekwentnie i w odniesieniu do cyrylicy, jak i - zapisów łacinką, w której podano thumaczenie tekstu ukraińskiego na język polski dokonane przez autora artykułu, oraz tekst będący transkrypcją fonetyczną tekstu cyrylickiego zawartego w chrestomatii. Transkrypcja półfonetyczna w zapisie łacinką została przeprowadzona przez autora artykułu na podstawie zapisu źródłowego w wersji ukraińskiego alfabetu literackiego.
}

16 Г. Аркушин, Голоси з Берестейщини..., op. cit., s. 303; pkt XXVII, 3. 
łyczkowyczy w rejonie kamienieckim: E.: Jak u was mówią we wsi na konia? Kuń - ne kiń, a kuń. E.: Na stoła [!]? - Stut. E.: Chodyt' czy chodyt? chodyt ${ }^{17}$.

W materiałach $\mathrm{z}$ Podlasia południowego informatorka ze wsi Wola Uhruska, powiat włodawski, spontanicznie wymienia jedną z wyróżniających cech swojej gwary: A w nas ,bul'e, chod'eli” [...] bo za Włodawoju, tam na Pidlasju: „,buli, chod'yli”'18.

b) Respondenci, identyfikując swoją gwarę, wskazują spontanicznie bądź inspirowani przez eksploratora na osobliwości leksykalne, por. przykłady z Polesia białoruskiego, ze wsi Woszczynycze: E.: U was mówią kartopla czy bulba? U nas różnie mówia: i kartoszka mówia i bulba - różnie mówia. [...] $N u$, tak bulba charaszaja ${ }^{19}$. Przywołana wypowiedź informatorki wskazuje na leksykalny rusycyzm w leksemie kartoszka i rdzenną, właściwą gwarze, nazwę bulba, wymienioną spontanicznie w końcowej części wypowiedzi.

Zróżnicowanie leksykalne gwar postrzegane jest - jak pokazuje zapis ze wsi Soboli, rejon berezowski - w rozmowie rdzennych mieszkańców i osób przybyłych z zewnątrz (najczęściej kobiet zamężnych); por.: dialog między autochtonem (A. I. Żełudko) a kobietą (N. S. Szybun-Kuhacz, ur. w r. 1957 w sąsiedniej wsi Stara Tebra), mieszkającą od kilkudziesięciu lat jako mężatka w Sobolach. Tekst przywołanej rozmowy ujawnia postrzeganie odmienności gwar we wskazywaniu osobliwości leksykalnych:

A. I. Żełudko: [...] w nas [tj. we wsi Sobole] mówia de twoj czołowik? Kudy on poszow?

N. S. Szybun-Kuhacz: Nie, w nas mużyk kuda poszow? [...] w Soboli-bulba, a w nas [Stara Tebra] - kartopli. Eto wot po tebrowsky kartopli nazywajecca. [...] w Briestie kartoszka ${ }^{20}$.

2. Podobieństwo pomiędzy gwarą wspólnot lokalnych Podlasia i Polesia a językiem ogólnoukraińskim

Wśród wypowiedzi respondentów reprezentujących lokalne wspólnoty pogranicza nadbużańskiego nierzadko występują sformułowania spontaniczne bądź inspirowane wykazujące podobieństwo lokalnej mowy do języka ogólnoukraińskiego.

Informator ze wsi Stary Brus w powiecie włodawskim tak formułuje swoje obserwacje: to taki podobny jenzyk do ukrajinskie... ukrajinskiego (mo maki подобни єзик бил до украӥнськє... українського) ${ }^{21}$.

Podobną opinię wypowiada informator pochodzący z Polesia białoruskiego, ze wsi Motol w rejonie iwanowskim, por. E.: U was tak samo mówią, jak

Ibidem, s. 67, pkt VIII, 3.

Idem, Голоси з Підляшшя..., op. cit. s. 29, pkt 1. 5.

Idem, Голоси з Берестейщини..., op. cit., s. 27, pkt II, 3.

Ibidem, s. 135, pkt XII, 13.

Idem, Голоси з Підляшия..., op. cit. s. 35, pkt 2.1. 
w Tyszkowyczach? Nie, tam trocha ynakszej [...] Nasza mowa pud .... pud ukrajinsku podobna ${ }^{22}$.

Mieszkańcy wspólnot lokalnych obwodu brzeskiego mają świadomość odmienności swojego języka, por. wypowiedź informatora ze wsi Rasna (rejon kamieniecki); por. tutaj u nas wszyscy mówia po-naszomu, tak mówią, po ukraińsku (tut u nas [...] wsi how'orat' po nasz'omu, tak k'ażut', po ukr ajinsku $)^{23}$.

Autor tekstów gwarowych z Polesia białoruskiego podaje we wstępie swojej chrestomatii obszerne fragmenty cytatów z wypowiedzi respondentów, zamykając niejako dyskusję na temat przynależności dialektalnej gwar brzesko-pińskich, prowadzoną pomiędzy językoznawcami białoruskimi i ukraińskimi ${ }^{24}$; por.:

Na nas nikt nie mówit, że jesteśmy Białorusinami, wszyscy mówili, że jesteśmy Ukraińcami. Zobaczcie, nasz język podobny do ukraińskiego (to nas nycht'o ny kaz'aw szo my bietor' usy, howor' yli wsi szo my wkraj'inci, nasz baczte, nasz jaz'yk, bulszunstw'o, sw'a jak'is', tak'ij o pud ukraj'inskyji pudch'odyt' ${ }^{25}$.

3. Język lokalnej wspólnoty ukraińskojęzycznej na Podlasiu południowym (w granicach Polski) i na Polesiu zachodnim (w granicach Białorusi) postrzegany jako mieszanina kilku języków

Część respondentów reprezentujących wiejską ludność Podlasia południowego (w granicach Polski) i Polesia zachodniego (w granicach Białorusi) określa mowę lokalnych wspólnot ukraińskojęzycznych jako mieszaninę, por. rozmowę prowadzoną we wsi Krzywowierzba, powiat włodawski:

E.: W jakim języku rozmawiacie? (śmieje się). Ja wiem, jak nazwać? Toż niby, my nazywamy się Ukraińcami, to i język ukrainski, ale to taka już mowa ukrajińska daleko przeplatana z polska (Я вєм як назвати? То ши ниби ми звемося украйнцями то й украӥнська мова, але то така вже украӥнська мова далєко переплетяна с польскою) $)^{26}$.

Podobną świadomość językową mają respondenci Polesia białoruskiego, por. Nasz jazyk [...] Jakyjs' takyj, o pud ukrajins'kij pudchodit' [...] i ruske pomiszany i ukrainske, a bietoruske $w$ nas nyma ${ }^{27}$.

4. Język lokalnej wspólnoty ukraińskojęzycznej na Podlasiu południowym (w granicach Polski) i na Polesiu zachodnim (w granicach Białorusi) postrzegany przez pryzmat jego funkcji

\footnotetext{
22 Idem, Голоси з Берестейщини..., op. cit., s. 217, pkt XX, 2.

23 Ibidem, s. 93.

24 Ibidem, s. 9-10.

25 Przywołana obserwacja zrodziła się w świadomości respondenta pochodzącego z obwodu brzeskiego, który z powodów rodzinnych odbył dłuższą podróż na Grodzieńszczyznę.

26 Idem, Голоси з Підляшия..., ор. cit. s. 63, pkt 5.6.

27 Idem, Голоси з Берестейщини..., op. cit., s. 333, pkt XXIX, 2.
} 
Spośród różnych funkcji języka jako najważniejsza wyłania się - z wypowiedzi respondentów - jego funkcja komunikacyjna. Bilingwizm jako charakterystyczna cecha wspólnot lokalnych południowego Podlasia i polilingwizm - na Polesiu białoruskim ${ }^{28}$ determinuje wybór języka jako środka komunikacji skierowanego do określonego terytorialnie, socjalnie i pokoleniowo środowiska. Rola komunikacyjna języka lokalnych wspólnot ukraińskojęzycznych znajdujących się poza terytorium oficjalnego funkcjonowania języka ogólnonarodowego powoduje, że pełni on też funkcję integracyjną. Łączy dane wspólnoty - dzięki opanowaniu reguł fonetycznych, gramatycznych i ich stosowaniu w ramach aktualnej normy językowej. Reguły i normy obowiązujące wiejskie wspólnoty ukraińskojęzyczne na obszarach południowego Podlasia (w granicach Polski) i zachodniego Polesia (w granicach Białorusi) są realizowane wyłącznie w subkodzie ustnym.

O sytuacjach komunikacyjnych zachodzących w obrębie wspólnot ukraińskojęzycznych mówią respondenci omawianej dwutomowej chrestomatii ${ }^{29}$.

Wybór języka wspólnoty lokalnej na Podlasiu południowym i Polesiu białoruskim jest warunkowany wiekiem rozmówców. Wśród członków rodzin wsi obwodu brzeskiego zdarza się, że najstarsze pokolenie posługuje się gwarą ukraińskojęzyczną i w tej gwarze rozmawia z młodszymi domownikami, mimo że ci młodsi już nie mówią ,po-naszomu”. Bywa i tak w obrębie wielopokoleniowej rodziny, że dzieci mówią po rosyjsku i (jeszcze ) lokalną gwarą ukraińską ,,po naszomu howorat", zaś wnuki tylko po rosyjsku. Sytuację taką dobrze ilustruje wypowiedź respondentki ze wsi Staromłyny, rejon drohiczyński) ${ }^{30}$.

O sytuacjach i zachowaniach językowych w rodzinie, w odpowiedzi na pytanie eksploratora: A kiedy przyjeżdżają do was wnuki, to w jakim języku rozmawiają? Te, które w Biełoozorsku, to wszystkie - po rosyjsku. Młodzi mówia po rosyjsku. I tak też $w$ domu rozmawiaja. I do mnie przyjeżdzają: „Babuszka...”. Wszystko po rosyjsku. [...] E.: Ale czy oni rozumieją, co Wy mówicie? To oni wszystko, bo oni tutaj wychowywali się, oni [jak się] wydaje rozumieja wszystko. Ale same mówią po rosyjsku, juz nie chca [mówić lokalną gwarą-F. Cz.]. Tak już i...i... młodsze córki mówia w większości, nu, ta gdzie trzeba po rosyjsku, a jak ... a jak tak z nami, po naszemu mówia. A zięć, on to dzieś z Rosji, Rosjanin (E.: A jak wnuky pryjiżdżajut', to z wamy po-jakomu howorat'? Za're wn'uky'onde h'ete, szo Bielooz'orsku, da j wsi t'yji, po r'uski mołod'yji how'orat', po-r'uski. I tak wd'oma how'orat', $j$ do... do men'e pryj'

28 O wielojęzyczności na Białorusi (szczególnie na jej pograniczach) z prac ostatnio opublikowanych przywołać należy monografię A. Żebrowskiej (A. Żebrowska, Komarowszczyzna. Język pogranicza białorusko-polsko-litewskiego, Poznań 2019) i książkę K. Konczewskiej (K. Konczewska, Polacy i język polski na Grodzieńszczyźnie, Kraków 2021).

29 Г. Аркушин, Голоси з Підляшшя..., op. cit.; idem, Голоси з Берестейщини..., op. cit.

30 Ibidem, s. 193, pkt. XVII, 6. 
idut': „B'abuszka...”. Ws'o po-r'uski. Ja ... ja h'inszyj raz każu ...E.: Ałe wony ponimajut', szczo wy howoryte? To won'y wse, bo ż won'y tut hodow'atysia wse, tak'i $\dot{z}$ wsi l'ude [...] wony sz tut 'onde, won'y ponim'ajut' us'e, w'idaj. A s' amy how'orat'po-ruski, wże ne... ne ch'oczut' [...] Da wże j-j d'oczky mot'otszi [...] d'oczky to nie, d'oczky how'orat'po bulszystw'o, nu, de tr'eba, to po r'uski, 'a jak ... 'a jak tak z n'amy, po-n'aszomu howorat'. A ziat', wyn to t'oże des' $z$ Rosi'ji, r'uski $)^{31}$.

5. Język wspólnoty ukraińskojęzycznej na Podlasiu południowym (w granicach Polski) i na Polesiu zachodnim (w granicach Białorusi) jako język wiejski, dieriewienski

Respondenci postrzegają niekiedy język wspólnot lokalnych jako odrębną mowę danej wsi, zaznaczając to $\mathrm{w}$ formie przymiotnika utworzonego od nazwy miejscowości. Ilustruje to dialog informatorki - ze wsi Motol, rejon iwanowicki, urodzonej w 1921 roku - z eksploratorem:

E.: Czy jesteście Białorusinką ? Uhu E.: A dlaczego nie mówicie po białorusku? My, motylanie mówiliśmy tak wszyscy i zawsze. [...] E.: To, w jakim języku mówicie? Po swojemu. Ja po polsku już w szkole mówiła [tj. uczyła się przed 1939 rokiem w szkole z nauczanym językiem polskim ? - F. Cz.].

E.: Ale, czy to jest język polski ? Przecież. E.: A może to język polski? Nie. E.: A żydowski? Nie [zaśmiała się]. E.: białoruski ? Nie. E: rosyjski ? Też nie [...] E: A do ukraińskiej mowy podobny czy nie? Nie. E.: A czy nie taki jest to język, jakim ja mówię?] Te.. ty Ukrainiec. E: A czy w waszej wsi tak się nie mówi? Nie, w nas motolska, swoja mowa byta ${ }^{32}$.

B. Język wspólnoty (jako historia mówiona) a język ogólnonarodowy

1. Elementami łączącymi społeczności lokalne Podlasia południowego i Polesia białoruskiego są wspólne doświadczenia historyczne. Dostarczyły ich wypadki dziejowe: zabór rosyjski, bieżeństwo roku 1915 i powroty po kilkuletnim pobycie $\mathrm{w}$ głębi Rosji na ziemie rodzinne.

Wiejską ludność ukraińskojęzyczną mieszkającą po obu stronach Bugu łączy także wspólne dziedzictwo wynikające z przynależności do II Rzeczypospolitej. Okres ten stanowi część historii mówionej respondentów wymienionych $\mathrm{w}$ chrestomatii. W wypowiedziach informatorów ukraińskojęzycznych - nawiązujących do okresu międzywojnia na Kresach - znajdują się odniesienia do skomplikowanych relacji konfesyjnych. Kwestie te są o tyle istotne dla rozpatrywanej tutaj problematyki „stereotypu mowy Ukraińca”, że doprowadziły do utworzenia zbitki językowej: „mowa prawosławna”. Znajdujemy to określenie w sformułowaniu respondenta ze wsi Moszczona-Królewska (w gminie Mielnik w powiecie siematyckim) na Podlasiu; por.

31 Ibidem, s. 193, pkt. XVII, 6.

32 Ibidem, s. 217, pkt XX, 2. 
odpowiedź na pytanie eksploratora: Jaka u was mowa? - U nas nazywajut'... czysto prawostawna „чисто православная” ${ }^{\prime 3}$.

2. Wspólnym doświadczeniem wiejskiej ludności Podlasia południowego i Polesia białoruskiego w kształtowaniu świadomości językowej były również wydarzenia II wojny światowej.

$\mathrm{Na}$ świadomość językową lokalnych wspólnot pogranicza polsko-wschodniosłowiańskiego wpływ wywarło także szkolnictwo ukraińskie z czasów okupacji niemieckiej. Chodzi mianowicie o tworzenie przez okupanta niemieckiego - na Podlasiu (od 1939 r.) i na Polesiu (od czerwca 1941 r.) - szkolnictwa ukraińskiego na poziomie podstawowym i zawodowym. Fakt ten stanowi trwały element historii mówionej, w tym kształtowania świadomości językowej. Wskazują na to respondenci ukraińskojęzyczni będący w latach 1939-1944 w wieku szkolnym. Znając wcześniej lokalny wariant gwary, mogli - w latach okupacji niemieckiej - poznawać w szkole podstawy literackiego języka ukraińskiego. Przyswajali więc jego reguły gramatyczne obowiązujące $\mathrm{i} w$ mowie, i w piśmie i w ten sposób znacznie pogłębiali swoją świadomość językową, którą mieli wcześniej tylko jako użytkownicy lokalnej gwary ${ }^{34}$.

H. Arkuszyn zamieścił w swej dwutomowej chrestomatii fragmenty wypowiedzi respondentów odnoszące się do nauczania języka ukraińskiego w czasach okupacji niemieckiej; por. hasło Szkoła ukrajińska (Школа українська) w indeksie rzeczowym w chrestomatii z Podlasia ${ }^{35}$ i hasło $O$ szkole (Пpo школу) zamieszczone w wyborze tekstów z Polesia białoruskiego ${ }^{36}$.

Wzorzec literacki ukraińszczyzny w szkole i w ośrodkach oświatowych kształtowany był wówczas na Podlasiu - według relacji respondentów - przez inteligencję (nauczycieli i księży) przybyłą z dawnej Galicji; por. zapis ze wsi Horostyta, powiat włodawski: des'z Galiicji buw nauczyciel jakys' 'to ${ }^{37}$.

Podobnie wypowiada się o szkole ukraińskiej informator pochodzący ze wsi Kostomłoty, powiat Biała Podlaska. Przywołuje on w swojej relacji przykłady zakładania w okresie okupacji niemieckiej szkół z nauczanym językiem ukraińskim: w czasie wojny była tutaj ukraińska szkoła [...] Po ukrajinsku my uczyli się. Tutaj byt, i.. i.. batiuszka, ukrajinskij prawosławanyj i nauczycielka byta. A potem [t.j. po odejściu Niemców]. Potem, potem wyjechali [tj. batiuszka i nauczycielka] $]^{38}$.

33 Idem, Голоси з Підляшия..., op. cit., s. 133, pkt 9. 9.

34 Dostrzec to można, obserwując powstałe w tym okresie ukraińskie inskrypcje nagrobne na cmentarzach Podlasia (por. F. Czyżewski, Antroponimia pogranicza polsko-wschodniosłowiańskiego w świetle inskrypcji nagrobnych. Część 1: Słownik nazwisk, Lublin 2013).

35 Г. Аркушин, Голоси з Підляшщя..., ор. cit., s. 532.

36 Idem, Голоси з Берестейщини..., op. cit., s. 16.

37 Idem, Голоси з Підляшия..., ор. cit., s. 53, pkt 4.2.

38 Ibidem, s. 97, pkt 7.11. 
Przywołane fragmenty wypowiedzi informatora z Kostomłot dotyczące nauczania języka ukraińskiego w okresie dzieciństwa wzbogaciły jego świadomość językową na temat istniejących powiązań między gwarą lokalną a językiem ogólnym. Świadczy o tym cytowana niżej rozmowa eksploratora z respondentem;

por.: E.: Do jakoji mowy wona błyżcza? Na mene, do ukrajins'koji, bo ja tut [w Kostomłotach] buw, w czasi wujny buła tut ukrajins'ka szkoła [ja] chodyw do ukrajins'koji [szkoły].

3. Obraz powiązań gwary lokalnej z językiem ogólnonarodowym w świetle wypowiedzi respondentów ukraińskojęzycznych południowego Podlasia i Polesia białoruskiego

Zagadnienie świadomości językowej respondentów o powiązaniach genetycznych zachodzących pomiędzy używanymi przez nich gwarami lokalnymi a językiem ogólnonarodowym zajmuje ważne miejsce w dwutomowej chrestomatii ${ }^{40}$. Zasadniczość tego aspektu jest zrozumiała, dotyczy on bowiem stale aktualnego pytania o relacje granic językowych i granic administracyjnych, państwowych.

Czy układają się one zgodnie, czy też odmiennie. Odpowiedź na tego typu pytania jest inspirowana przez eksploratora następującym pytaniem kierowanym do informatorów-użytkowników lokalnej gwary wschodniosłowiańskiej: „Z jakim językiem ogólnonarodowym jest ona spokrewniona?”, „Do jakiego języka jest gwara ta bliższa?” (До якої мови вона ближча?). Por. dialog eksploratora z respondentem ze wsi Kostomłoty, w powiecie Biała Podlaska, zamieszczony wcześniej.

Podobne konstrukcje pytań zawiera rozmowa eksploratora prowadzona na Polesiu białoruskim, we wsi Chryso, w rejonie berezowskim, por.: E.: W jakim języku wy mówicie? (Якою мовою ви говорите?). 75-letnia informatorka, autochtonka, mieszkająca na Polesiu białoruskim odpowiada: $A$ czy ja wiem w jakim języku rozmawiamy (А я відаю якою мово говоримо?). Wspomogające pytania eksploratora dotyczą potwierdzenia/zaprzeczenia istnienia w wymowie respondentki - mieszkanki obwodu brzeskiego - wyrazistych cech literackiego języka białoruskiego, jakimi są: dziakanie i ciakanie; E.: Wy dziekajecie i ciekajecie czy nie ? (Ви дзекаєце і цєкаєцє чи нє ? ) [...] Wy mówicie chadziła? (Ви кажете хадзіла?). Odpowiedź zawiera zaprzeczenie wymienionych cech i przywołanie właściwej respondentce wymowy, tj. stwierdzenie istnienia wymowy typu - chodyta.

Pytanie dodatkowe kierowane do informatorki, które - według eksploratora - powinno wskazać na przynależność genetyczną gwary wsi Chryso w rejonie berezowskim, brzmi: E.: Do jakiego języka ta gwara jest bliższa? (До якої мови ближча ?). To pytanie pozostaje bez rozstrzygającej odpowie-

$39 \quad$ Ibidem, 97, s. pkt 7. 11.

40 Ibidem; idem, Голоси з Берестейщини..., op. cit. 
dzi o przynależność dialektalną gwary, por. Oj, Bóg wie, ja - nie wiem (Oü Господь його відає, не знаю) ${ }^{41}$.

Przywołane z chrestomatii dwa przykłady - ze wsi: Kostomłoty (Podlasie) i Chryso (Polesie białoruskie) - wskazują na różną świadomość językową respondentów. Przedstawiciel wspólnoty lokalnej ze wsi Kostomłoty na Podlasiu poznał w przeszłości literacki język ukraiński. Natomiast respondentka ze wsi Chrysowo ma świadomość językową znajdującą się na poziomie gwary lokalnej, języka wiejskiego.

Można więc stwierdzić, że obraz gwary lokalnej, języka i jego powiązań z językiem ogólnonarodowym zależy między innymi od stopnia wykształcenia respondentów i od ich umiejętności obserwacji języka sąsiednich grup lokalnych.

4. O zróżnicowanej świadomości językowej wiejskiej ludności nadbużańskiej w przypadku młodszych respondentów - jak pokazują teksty analizowanych tomów chrestomatii - decyduje także mobilność, zdolność przemieszczenia się.

Świadomość językowa mieszkańców lokalnych wspólnot ukraińskojęzycznych w granicach Polesia białoruskiego może kształtować się poprzez konfrontację języka innych wspólnot wschodniosłowiańskich znajdujących się na terytorium Białorusi.

Dobrze ilustruje to stwierdzenie przykład ze wsi Pisky w rejonie kobryń$\mathrm{skim}^{42}$. W odpowiedzi na pytanie eksploratora o różnicę między mową mieszkańców wsi Pisky a mową mieszkańców dalszych wsi respondent przywołuje swoje obserwacje, wynikające z porównania języka mieszkańców obwodu brzeskiego do języka mieszkańców Grodzieńszczyzny.

Oto wypowiedź informatorki: Wy znajete szop u nas takij interesnyj jazyk. Ot mene brata... mużyka brat... My zajichaty [do Wołkowyska] to nas nichto ni kazaw, szo my Biełorusy - howoryly wsi, szo my Wkrajinci. [...] Nasz jazyk bulszynstwo swja.. Jakyjs 'takyj, o pud ukrajins/kij pudchodit', ich [tj. na Grodzieńszczyźnie] cie takieje o, stowo ge i ruske pomiszany i ukrainske, a bietoruske w nas nyma. Ot ja sama uczyłasia w szkoli bieała... biełaruskij jazyk to „chadził, rabił”. Nu, my tak ny howyrymo. E.: A jak wy zapisany? Biełorusy ${ }^{43}$.

\section{WNIOSKI}

Sytuacja językowa wspólnot ukraińskojęzycznych na Podlasiu południowym i Polesiu białoruskim jest podobna. Język ukraiński wspólnot lokalnych i w Polsce, i na Białorusi jest językiem najstarszego pokolenia.

\footnotetext{
$41 \quad$ Ibidem, s. 171, pkt 4.1.

42 Ibidem, s. 333, pkt XXIX. 2.

43 Ibidem, s. 333, pkt XXIX, 2.
} 
Obraz świadomości językowej mieszkańców pogranicza polsko-wschodniosłowiańskiego jest zróżnicowany. Warunkowany jest między innymi stopniem ich wykształcenia, mobilnością i umiejętnością obserwacji języka sąsiednich i dalszych grup lokalnych. Ważna jest umiejętność postrzegania związków genetycznych swojej lokalnej gwary z językiem ogólnonarodowym w warunkach dwu- i wielojęzyczności jej funkcjonowania. Taka sytuacja językowa występuje - jak pokazują analizowane teksty chrestomatii - i na Podlasiu w granicach państwa polskiego, i na zachodnim Polesiu w graniach państwa białoruskiego.

\section{BIBLIOGRAFIA}

Arkušin Grigorìj. 2007. Golosi z Pidlâššâ (Teksti). Luc'k: Veža [Аркушин Григорій. 2007. Голоси з Підляшия (Тексти). Луцьк: Вежа].

Arkušin Grigorìj. 2010. Golosi z Volins'kogo Polìssâ (Teksti). Luc'k: Veža [Аркушин Григорій. 2010. Голоси з Волинського Полісся (Тексти). Луцьк: Вежа].

Arkušin Grigorìj. 2012. Golosi z Berestejsisini (Teksti). Luc'k: Volins'kij nacìonal'nij unìversitet ìm. Lesì Ukraïnki [Аркушин Григорій. 2012. Голоси з Берестейщини (Тексти). Луцьк: Волинський національний університет ім. Лесі Українки].

Czyżewski Feliks. 2013. Antroponimia pogranicza polsko-wschodniosłowiańskiego $w$ świetle inskrypcji nagrobnych. Część 1. Słownik nazwisk. Lublin: Wydawnictwo Polihymnia.

Konczewska Katarzyna. 2021. Polacy i język polski na Grodzieńszczyźnie. Kraków: Instytut Języka Polskiego PAN.

Pelcowa Halina. 2013. Gwara jako nośnik lokalnego i regionalnego dziedzictwa kulturowego. W: Niematerialne dziedzictwo kulturowe: źródło - wartości - ochrona. Red. Adamowski J., Smyk K. Lublin - Warszawa: Wydawnictwo UMCS: 219-229.

Pelcowa Halina. 2016. Gwara - dziedzictwo ciagle żywe czy już zapomniane? „Język Polski” r. 96: 5-14.

Pelcowa Halina. 2019. Dialektologia jako nauka i przedmiot dydaktyki. W: Język i kultura pogranicza. Red. Dudek-Szumigaj A. Warszawa: Stowarzyszenie Współpracy Polska-Wschód: 55-64.

de Saussure Ferdynand. 1991. Kurs językoznawstwa ogólnego. Wstęp i przypisy Polański K. Wyd. II, poprawione. Warszawa: Wydawnictwo Naukowe PWN.

Żebrowska Anna. 2019. Komarowszczyzna. Język pogranicza białorusko-polsko- litewskiego. Poznań: Wydawnictwo Naukowe Uniwersytetu i. Adama Mickiewicza w Poznaniu.

\section{STEREOTYP MOWY UKRAIŃCA W ŚWIETLE HISTORII MÓWIONEJ (NA PODSTAWIE CHRESTOMATII HOLOSY Z PIDLASZSZIA I HOLOSY Z BERESTEJSZCZYNY HRYHORIJA ARKUSZYNA)}

Streszczenie: W artykule przedstawiono, z wykorzystaniem metody socjolingwistycznej, obraz świadomości językowej ukraińskojęzycznych wspólnot zamieszkujących Podlasie południowe i Polesie białoruskie. Wskazano, wyzyskując wypowiedzi respondentów 
zawarte $\mathrm{w}$ dwóch tomach chrestomatii, na cechy zarówno łączące te dwie grupy użytkowników gwary ukraińskiej, jak i odróżniające oraz wyodrębniające je. Do elementów wspólnych tkwiących w świadomości lokalnych grup, a wynikających z doświadczeń historycznych respondentów, należą odniesienia do czasów II Rzeczypospolitej. Są to: wspólne terytorium państwowe i złożone relacje językowe oraz konfesyjne (por. „,mowa prawosławna"). Inną cechą łączącą, jak pokazano w przywołanych wypowiedziach respondentów ukraińskojęzycznych, jest podobna sytuacja komunikatywna. Wspólnoty lokalne na Podlasiu południowym, podobnie jak na Polesiu białoruskim, funkcjonują w warunkach bilingwizmu (niekiedy nawet w warunkach wielojęzyczności). W artykule przedstawiono sytuacje ,przełączania kodu językowego". Opisano je z perspektywy socjolingwistycznej, uwzględniając m.in. kryteria wieku i wykształcenia respondenta.

Odrębnym i ważnym zagadnieniem - w świetle wypowiedzi respondentów - jest obserwacja świadomości językowej wspólnot usytuowanych poza granicami państwowymi w zakresie powiązań genetycznych gwary z językiem ogólnonarodowym. Poddane analizie wypowiedzi respondentów reprezentujących wspólnoty ukraińskojęzyczne w Polsce i na Białorusi pokazują zróżnicowany stan świadomości językowej owych społeczności. Jedni (nieliczni) wiążą język ze świadomością narodową, inni pojmują język jako wyznacznik identyfikacji ze wspólnotą lokalną. W artykule przywołano wypowiedzi respondentów uzasadniające zróżnicowanie stanu świadomości wspólnot ukraińskojęzycznych. Są to m.in.: wiek, wykształcenie, stopień mobilności użytkowników języka i zdolność jego obserwacji.

Słowa kluczowe: dialekty, socjolingwistyka, Podlasie południowe i Polesie białoruskie.

\section{СТЕРЕОТИП МОВЛЕННЯ УКРАЇНЦЯ У СВІТЛІ УСНОЇ ІСТОРІЇ (НА ОСНОВІ ХРЕСТОМАТІЙ ГОЛОСИ 3 ПІДЛЯШШЯ ТА ГОЛОСИ 3 БЕРЕСТЕЙЩИНИ ГРИГОРІЯ АРКУШИНА)}

Анотація: У статті представлено картину мовної свідомости україномовних спільнот, які проживають на Південному Підляшші та білоруському Поліссі, з використанням соціолінгвістичного методу. Використовуючи висловлювання респондентів, що містяться у двох томах хрестоматій, було вказано як на прикмети, що пов'язують ці дві групи носіїв української говірки, так і на прикмети, що відрізняють та виокремлюють їх. До загальних елементів, які наявні у свідомості місцевих груп, що є результатом історичного досвіду респондентів, належать згадки про часи Другої Речі Посполитої. Це спільна державна територія та складні мовні і конфесійні відносини (пор. “православна мова”). Ще однією спільною рисою, як показано у цитованих висловлюваннях україномовних респондентів, $є$ подібна комунікативна ситуація. Місцеві спільноти на Південному Підляшші, як і на білоруському Поліссі, функціонують в умовах двомовності (іноді навіть в умовах багатомовности). У статті представлені ситуації “переключення мовного коду”. Вони описані з соціолінгвістичної точки зору, беручи до уваги, зокрема, критерії віку та освіти респондента.

Окремим і важливим питанням - у світлі висловлювань респондентів - $\epsilon$ спостереження за мовною свідомістю громад, що проживають за межами державних кордонів, у сфері генетичних зв'язків мови користувачів говірки з загальнонаціональною мовою. Аналізовані вислови респондентів, які представляють україномовні спільноти у Польщі та в Білорусі, засвідчують про різний рівень мовної свідомос- 
ти їх користувачів. Деякі респонденти (нечисленні) пов'язують мову з національною ідентичністю, інші розуміють мову як детермінант ідентифікації з місцевою спільнотою. У статті приведено вислови респондентів, які обгрунтовують різноманітність стану свідомості україномовних спільнот. Це, зокрема, вік, освіта, ступінь мобільности користувачів мови та здатність спостерігати за нею.

Ключові слова: слов'янська діалектологія, соціолінгвістика, Південне Підляшшя, білоруське Полісся. 